\title{
Konsep Rational Emotive Behaviour Therapy (Rebt) Dalam Usaha Mencegah Juvenile Delinquency
}

\author{
Alvin Koswanto \\ STT Ekumene Jakarta \\ Mal Artha Gading Lt. 3, Jl. Artha Gading Selatan No 1 Kelapa Gading, Jakarta Utara 14240 \\ Email: alvin.koswanto@sttekumene.ac.id
}

\begin{abstract}
ABSTRAK
Perkembangan sosial pada remaja menyebabkan mereka lebih memilih untuk menghabiskan waktu dengan komunitas atau kelompok teman-teman sebayanya. Hal ini menjadi sebuah permasalahan, apabila remaja bergabung pada komunitas atau kelompok yang salah, akan membuat mereka memiliki nilai-nilai yang salah sehingga berani untuk melakukan juvenile delinquency (kenakalan remaja). Oleh karena itu, penelitian ini ditulis dengan tujuan memberikan masukan kepada orangtua maupun gereja dalam memberikan keyakinan atau kepercayaan yang rasional, sehingga remaja tidak sampai melakukan tindakan atau perbuatan yang melanggar norma-norma yang ada di masyarakat. Metode yang digunakan adalah penelitian kepustakaan dengan jenis analisis buku teks. Hasil dari penelitian ini adalah ditemukan konsep belief yang rasional, untuk mengganti kepercayaan atau keyakinan remaja yang irasional dengan harapan remaja tidak menunjukkan perilaku kenakalan remaja.
\end{abstract}

Kata kunci: kenakalan remaja; REBT; belief; sosial; perkembangan sosial

\section{ABSTRACT}

Social development in adolescents causes them to prefer for a long time with the community or group of peers. This becomes a problem, if teenagers join the wrong community or group, they will have the wrong values so they dare to commit juvenile delinquency. Therefore, this research was written with the aim of providing input to parents and the church in providing rational beliefs or beliefs, so that adolescents do not take actions or actions that violate the norms that exist in society. The method used is library research with the type of textbook analysis. The result of this study is the discovery of the concept of rational belief, to replace irrational adolescent beliefs or beliefs with the hope that adolescents do not show juvenile delinquency.

Keywords: juvenile delinquency; REBT; belief; social; social development

\section{PENDAHULUAN}


Beberapa waktu belakangan ini, dunia media sosial digemparkan oleh adanya viral "Challenge Malaikat Maut” yang menyebabkan kematian seorang remaja. Tindakan ini rupanya sudah berkali-kali dilakukan oleh remaja tersebut bersama dengan beberapa rekannya. Mereka adu kuat dengan mencoba memberhentikan truk yang sedang melintas. Ketika truk tersebut berhenti, maka mereka akan lari (Aji, 2021). Kenakalan remaja seperti ini tentunya bukan pertama kalinya terjadi dan akhirnya menjadi sorotan publik. Ada pula kenakalan remaja lainnya yang kerap menjadi viral, seperti gerombolan remaja acungkan clurit di Karawang (Supiandi, 2021), tawuran remaja yang dipicu oleh saling ejek di media sosial (Surjaya, 2021), seorang remaja 13 tahun yang secara tidak sengaja membakar dirinya sendiri harus menjalani perawatan intensif selama dua minggu. Hal ini dikarenakan remaja itu meniru tantangan yang viral di Tik Tok (Rossa, 2021).

Masa remaja merupakan masa yang penuh dengan perubahan. Perubahan dalam diri remaja ada yang dapat terlihat secara jelas, seperti perubahan pada fisik mereka dimana badan mulai tinggi, bertumbuhnya alat kelamin primer maupun sekunder, dan sebagainya. Ada juga perubahan yang tidak dapat dilihat secara kasat mata namun dapat dirasakan oleh para orangtua, atau orang-orang yang mempunyai hubungan dengan mereka, seperti perubahan kecerdasan, emosi, kerohanian, dan salah satunya adalah sosial (Fhadila, 2018). Hal ini merupakan hal yang wajar dikarenakan masa remaja merupakan masa ketika seorang anak muda harus beranjak dari ketergantungan menuju kemandirian, otonomi, dan kematangan (Geldard \& Geldard, 2011).

Perubahan sosial yang dialami oleh seorang remaja membuat dia mengalami pergeseran juga dalam nilai-nilai sosial. Hal tersebut dapat terlihat ketika remaja tersebut mulai lebih memilih teman-teman atau komunitasnya dibandingkan keluarganya (Fhadila, 2018). Perubahan atau pertumbuhan sosial yang dialami oleh remaja dikarenakan adanya konflik mendekat-menjauh, dimana konflik ini muncul dari dalam diri seseorang yang dikarenakan adanya dua rangsangan, yaitu rangsangan positif (rangsangan yang ditimbulkan oleh teman-temannya) dan rangsangan negatif (rangsangan yang ditimbulkan oleh keluarganya) (Koswanto \& Hutagalung, 2019). Tentunya, hal tersebut membuat hubungan remaja dengan keluarganya menjadi tidak harmonis atau terjadi kerenggangan.

Perubahan tersebut menghadirkan tantangan tersendiri bagi diri seorang remaja. Tantangan tersebut berkenaan dengan kebutuhan remaja tersebut untuk menemukan 
tempat mereka dalam masyarakat dan merasakan bahwa tempat tersebut sesuai dengan keinginan dan harapan. Hal tersebut akhirnya membuat banyak remaja ingin bergabung dengan komunitas atau kelompok yang selama ini sudah ada, baik di lingkungan sekolah maupun lingkungan masyarakat. Jika tidak menemukan yang sesuai dengan keinginan dan harapannya, maka mereka akan membuat kelompok atau komunitas yang baru. Dan jika sudah terbentuk, mereka akan mengajak remaja-remaja lainnya untuk bergabung. Dengan adanya ajakan tersebutlah, maka para remaja akan berusaha melakukan apapun supaya dapat diterima oleh kelompok atau komunitas yang mereka sukai. Para remaja akan berperilaku yang dapat diterima secara sosial, memainkan peran sosial yang dapat diterima di lingkungan masyarakat, dan mengembangkan sifat sosialnya (Hurlock, 1995).

Remaja dalam melakukan tindakan kenakalan remaja tidak hanya dilakukan secara individual, tetapi juga dilakukan secara bersama-sama atau berkelompok. Beberapa tindakan kenakalan remaja yang sering dilakukan seperti memakai narkoba, pencurian, balap liar, tawuran, dan sebagainya (Nopiansyah, 2021). Tindakan kenakalan yang dilakukan para remaja hanya akan menyenangkan diri sendiri dan teman-teman sebayanya saja. Hal inilah yang menjadi problematika tersendiri bagi orangtua maupun gereja, dikarenakan banyaknya komunitas atau kelompok yang beranggotakan para remaja dengan segala jenis karakteristiknya. Remaja yang sedang mencari jati diri, tentunya akan memiliki segudang kehidupan sosial. Dan lewat komunitas atau kelompok dimana remaja tersebut bergabung, akan menentukan siapa dan bagaimana kehidupan mereka di masa depan nanti. Dengan hidup secara berkomunitas atau berkelompok, maka remaja memiliki kerentanan terhadap perilaku atau tindakan yang dapat menyimpang dari moral, hukum, agama, dan sebagainya.

Di satu sisi, perubahan sosial remaja ini menjadi tantangan tersendiri bagi keluarga dan gereja. Keluarga (dalam hal ini orangtua) maupun gereja perlu melakukan pembinaan atau pengarahan kepada remaja, agar tidak salah dalam memilih pergaulan (komunitas atau kelompok). Namun, penelitian yang telah dilakukan oleh Agus Sanjaya menjelaskan bahwa banyak hamba Tuhan atau pendeta sebagai gembala yang bertanggung jawab terhadap jemaatnya, tidak konsen terhadap pelayanan pastoral konseling, ini ditandai kurang dipersiapkannya pemimpin komsel yang ditugaskannya untuk memimpin dan membimbing remaja dengan ilmu-ilmu konseling, sedangkan 
remaja sangat membutuhkan bimbingan atau pendampinngan agar mereka tidak terpengaruh oleh pergaulan bebas (Sanjaya, 2018).

Pendeta/pastor/konselor tidak hanya hadir dan berperan sebagai pengkhotbah di atas mimbar yang memberikan Firman Tuhan, nasihat, teguran, dan ajaran pada konselenya; karena mereka berhadapan muka sebagai pribadi yang utuh, yang masingmasing hak untuk mengekspresikan dirinya (Widodo, 2016). Salah satu model konseling pastoral dalam mengatasi kenakalan remaja adalah model realitas. Menurut Zimpfer dalam (Widodo, 2016), terapi realitas terbukti efektif dalam upayanya membantu mengatasi persoalan perilaku menyimpang di kalangan remaja, khususnya untuk menangani remaja yang sering melanggar hukum. Selain terapi realitas, penelitian yang pernah dilakukan sebelumnya berkaitan dengan REBT juga telah dilakukan oleh Sri Hartati dan Imas Kania Rahman dalam membantu siswa membangun perilaku etis.

Baik keluarga maupun gereja, mempunyai harapan yang sama, yaitu para remaja akan cenderung untuk mengembangkan suatu kesadaran diri yang positif (Geldard \& Geldard, 2011). Oleh karena itu, peneliti menulis artikel ini untuk memberikan masukan kepada orangtua maupun gereja dalam memberikan keyakinan atau kepercayaan yang rasional pada remaja melalui teknik konseling REBT dengan model ABCDE, sehingga mereka tidak melakukan tindakan atau perbuatan yang melanggar norma-norma yang ada di masyarakat.

\section{METODE}

Dalam melakukan penelitian ini, peneliti menggunakan metode Library Research atau Penelitian Kepustakaan yang dapat dipahami sebagai penelitian yang dilaksanakan dengan menggunakan literature (kepustakaan), baik dari buku, catatan, maupun laporan hasil penelitian terdahulu (Hasan, 2008). Jenis penelitian kepustakaan yang digunakan dalam penelitian ini adalah analisis buku teks, dimana peneliti mengimplementasikan model ABCDE untuk membantu memberikan pemikiran yang rasional kepada remaja berkenaan dengan tindakan, pikiran, dan perasaan yang dapat mengendalikan perilaku kenakalan pada remaja. Untuk memperoleh data, peneliti mengumpulkan buku-buku dan artikel-artikel jurnal yang membahas mengenai konsep REBT, kemudian mengelompokan berdasarkan tingkat kepentingannya (primer, sekunder, dan tersier). Hasil dan pembahasan yang peneliti paparkan dalam artikel ini 
dimulai dari teori-teori, kemudian dilanjutkan dengan penjelasan hasil analisis. Pada bagian akhir, akan dipaparkan kesimpulan dari penelitian yang telah dilakukan.

\section{HASIL DAN PEMBAHASAN}

\section{Rational Emotive Behavior Therapy (REBT)}

\section{Konsep REBT}

Rational Emotive Behavior Therapy atau yang disingkat dengan REBT merupakan teknik konseling yang diciptakan oleh Albert Ellis pada tahun 1995. Teknik konseling REBT ini mencakup pikiran, perasaan, dan perilaku si konseli. Albert Ellis menyadari bahwa emosi, perilaku, dan pikiran tidak dapat dipisahkan antara satu dengan yang lainnya. Oleh karena itu, ketika konselor menggunakan teknik ini, perlu mengingat bahwa emosi dalam diri manusia itu penting, tetapi kognisi sesesorang adalah sumber berbagai masalah psikologis (Erford, 2020). Dalam teknik ini, konselor perlu membantu memberikan bantuan kepada konseli yang mengalami peristiwa, sehingga memerlukan konselor, bahwa perasan yang muncul dalam diri konseli tidak diakibatkan oleh peristiwa maupun orang lain yang terlibat dalam sebuah peristiwa, tetapi dikarenakan pikiran yang dikembangkan di dalam dirinya.

REBT melandaskan konsepnya pada sebuah teori, yaitu mengubah keyakinan irasional menjadi keyakinan yang fleksibel dan rasional, perubahan yang lebih adaptif dari konsekuensi perilaku dan emosional dapat terjadi. Dalam hal ini, Dryden\&David dalam (Erford, 2020) menjelaskan bahwa yang menjadi tujuan utama dalam teknik konseling REBT ini adalah membantu klien dalam memperjuangkan unconditional selfacceptance (menerima diri sendiri tanpa syarat), unconditional other-acceptance (menerima orang lain tanpa syarat), dan unconditional life-aceptance (menerima hidup tanpa syarat).

Corey dalam Erlina \& Sari (2016) juga menjelaskan bahwa REBT adalah salah satu metode penyelesaian masalah yang berfokus pada aspek berpikir, menilai, memutuskan, direktif tanpa lebih banyak berurusan dengan dimensi-dimensi pikiran ketimbang dengan dimensi-dimensi perasaan (Erlina \& Sari, 2016). Dari beberapa penjelasan diatas, maka dapat disimpulkan bahwa REBT merupakan tekhnik konseling yang digunakan untuk menolong konseli dalam menghadapi permasalahan yang muncul 
dengan mengubah keyakinan atau pemikiran yang irasional menjadi rasional sehingga berdampak pada perilaku yang ditimbulkan.

\section{Implementasi Model ABCDE}

Salah satu model yang erat dengan REBT adalah model ABCDE. Adapun yang dimaksud dengan A adalah Activating Event (kejadian pengaktif) dimana hal ini merupakan situasi atau kejadian yang menimbulkan keyakinan di dalam diri seseorang, seperti sebuah kejadian yang terjadi atau disimpulkan terjadi (baik terjadi secara internal/dialami diri sendiri atau eksternal, berkaitan dnegan masa lalu, sekarang, atau yang akan datang). Dalam hal ini, konselor perlu memahami mengenai apa yang sebenarnya terjadi dalam atau terhadap diri konseli; termasuk persepsi konseli terhadap sesuatu yang terjadi tersebut.

B merupakan belief (kepercayaan); ada dua jenis, yaitu rasional dan irasional.Keyakinan atau kepercayaan ini sangat penting diperhatikan karena mempengaruhi pikiran dan tindakan seseorang.Keyakinan rasional merupakan keyakinan yang realistis atau masuk akal dan dapat didukung oleh buktibukti.Keyakinan rasional bersifat tidak kaku dan logis, serta membantu konseli untuk mencapat tujuan.Sedangkan keyakinan irasional merupakan keyakinan yang tidak realistis dan sering kali berdasarkan pada absolutistic musts (keharusan mutlak).Keyakinan irasional lebih bersifat kaku dan tidak membantu konseli untuk mencapai tujuan. Biasanya, keyakinan irasional yang dimiliki oleh konseli, lebih kearah merendahkan diri atau menyalahkan orang lain.

C merupakan consequence, dimana ini merupakan bentuk luapan dari keyakinan yang dimiliki oleh konseli terhadap kejadian pengaktif, yang diwujudkan dalam bentuk perilaku. Pada umumnya, consequence inilah yang membuat konseli mulai mencari seorang konselor untuk membantunya. Bradley mengutip pendapat Dryden yang menjelaskan bahwa emosi-emosi negatif seperti kekhawatiran, kesedihan, penyesalan dan kesusahan adalah respon yang sehat; semenetara kecemasan, depresi, rasa bersalah, dan merasa terluka adalah respon yang tidak sehat (Erford, 2020).

D merupakan dispute, dimana konselor melakukan pertentangan terhadap keyakinan irasional yang dimiliki oleh konseli terhadap kejadian pengaktif.Ada tiga bentuk D ini, yaitu debating (memperdebatkan), discriminating (memperbedakan), dan defining (mendefinisikan).Konselor dapat memberikan juga pertanyaan-pertanyaan 
yang membahas mengenai keyakinan irasional yang dimiliki oleh konseli, dan membantunya untuk dapat membedakan antara keyakinan yang rasional dengan yang irasional.

Setelah melakukan D, maka konselor dapat melakukan E, yaitu effects. Jika di tahap D tersebut konselor berhasil membantu konseli untuk merubah keyakinan yang dimiliki, maka ia akan merubah perasaan dan perilakunya. Hal ini dapat mengakibatkan, apabila konseli mengalami A lagi, maka ia dapat menarik sebuah kesimpulan yang rasional.

Model ABCDE ini secara sederhana dapat dibuat bagan seperti ini:

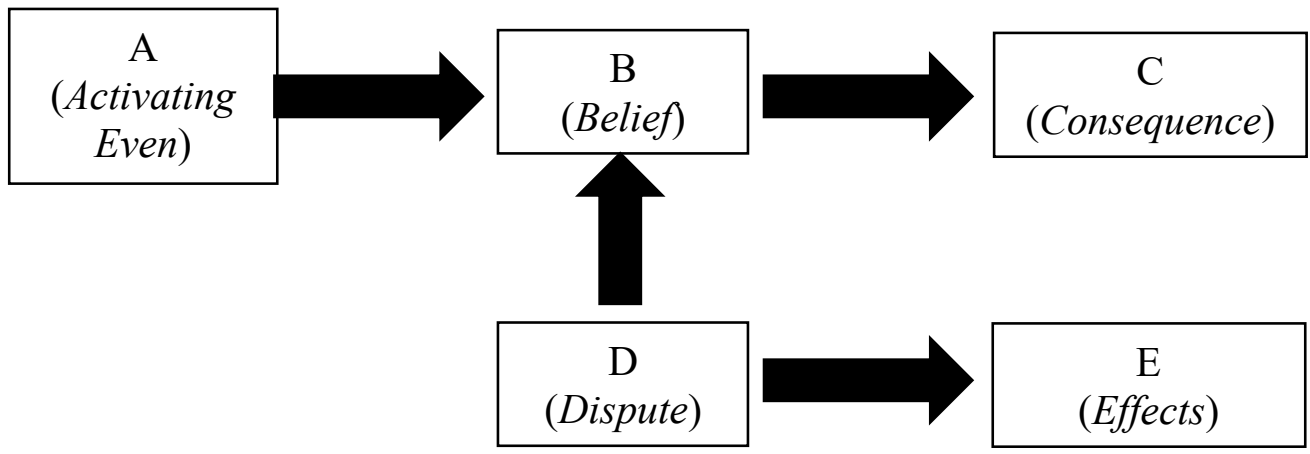

\section{Langkah-Langkah Melakukan REBT}

Ellis dalam (Erford, 2020) memberikan ada tujuh langkah dalam melakukan REBT terhadap konseli, yaitu: Mengakses self-talk pada konseli. Pada tahap ini, konselor mengarahkan kepada konseli untuk membicarakan mengenai presenting issue atau masalah yang dihadapi, yang membuat konseli untuk melakukan konseling. Artinya, ini kesempatan konselor untuk mengungkap model A dan $\mathrm{C}$ yang dialami oleh konseli.

Menentukan keyakinan yang mendasari konseli. Dari self-talk yang telah dilakukan, konselor berusaha menemukan apa yang menjadi kepercayaan atau keyakinan yang dimiliki konseli ketika menghadapi permasalahan tersebut. Konselor berusaha menyadarkan konseli mengenai keyakinan-keyakinan irasional yang dipercayai sehingga berdampak pada nilai-nilai yang dipahami serta perilaku yang dikembangkan. Tahap ini akan membantu konseli untuk memahami bagaimana dan mengapa permasalahan tersebut dapat terjadi irasional.

Membuat kesepakatan terhadap konseli mengenai suatu keyakinan yang lebih rasional. Jika keyakinan yang dimiliki konseli bersifat irasional, maka perlu dibuat kesepakatan dengan konselor mengenai keyakinan yang lebih rasional dan tepat, untuk 
mencapai perasaan dan konsekuensi yang diinginkan. Konselor membantu dan meyakinkan kepada konseli, bahwa dirinya berpotensi untuk mengubah keyakinan atau pemikiran yang negatif atau tidak logis dengan keyakinan atau pemikiran yang positif atau logis (Hartati, Sri \& Rahman, 2018).

Melaksanakan rational-emotive imagery (REI). Tahap REI ini dilakukan dengan tujuan menolong konseli untuk dapat mengidentifikasi emosi dan keyakinan yang layak dan rasional dalam menghadapi permasalahan; dan mengeksplorasi self-statement yang dimiliki oleh konseli. Dengan melakukan tahap ini, maka konseli akan menjadi mudah dan siap dalam menghadapi situasi yang menekan (Marlina et al., 2021).

Memberikan tugas kepada konseli untuk dilakukan. Konseli diberikan tugas untuk melakukan REI terhadap masalah yang dihadapi konseli sebanyak tiga sampai lima kali setiap harinya. Hal ini bertujuan untuk mengembangkan keyakinan rasional dan mengembangkan akan filosofi hidup yang rasional sehingga konseli tidak terjebak pada permasalahan yang dikarenakan pemikiran yang irasional tersebut. Ada dua tugas utama konselor yang harus dilakukan kepada konseli pada tahap ini, yaitu interpersonal dimana konselor membangun hubungan terapeutik, membangun rapport, dan suasana yang kolaboratif; dan organizational dimana konselor bersosialisasi dengan konseli untuk memulai terapi, mengadakan tinjauan awal, menyetujui wilayah masalah, dan membangun tujuan konseling (Komalasari et al., 2011).

Memberikan konsekuensi positif. Konsekuensi positif ini diistilahkan sebagai bentuk penghargaan oleh konseli terhadap dirinya sendiri, karena telah mengerjakan tugas yang diberikan. Hal ini sangat diperlukan agar memberikan semangat kepada konseli untuk terus meningkatkan pemikiran dan keyakinan yang rasional sehingga perilaku positif terus dimunculkan dan dikembangkan.

Memberikan konsekuensi negatif. Konsekuensi negatif ini kebalikan dari konsekuensi positif, dimana konseli melakukan hukuman terhadap dirinya sendiri, dikarenakan tidak mengerjakan tugas yang diberikan. Konsekuensi negatif diberikan dengan tujuan menyadarkan konseli akan perilaku yang belum berubah.

Ellis menjelaskan bahwa memproses sebuah permasalahan konseli dengan menggunakan pedoman atau langkah-langkah REBT ini, membutuhkan waktu 20-50 menit.

REBT ini merupakan cara efektif untuk membantu orang-orang yang berpikir lebih rasional, tidak terlalu merasa cemas, depresi, dan marah ketika gagal dan ditolak 
(Erford, 2020). REBT ini juga dinilai efektif dalam mengurani perilaku-perilaku negatif pada anak-anak dan remaja. Meskipun demikian, teknik REBT ini masih memiliki kelemahan, seperti tidaknya melihat masa lalu konseli dan keberhasilan teknik ini akan mengalami keterbatasan ketika dilakukan pada konseli yang memiliki gangguan kepribadian berat, seperti penyalahgunaan alkohol dan obat-obatan terlarang, pencurian, $\mathrm{dsb})$.

\section{Juvenile Delinquency}

\section{Pengertian Juvenile Delinquency}

Istilah juvenile delinquency berasal dari bahasa latin yang artinya adalah kenakalan remaja. Juveline yang memiliki akar kata juvelinis memiliki pengertian "anak-anak, anak muda, ciri karakteristik pada masa muda, sifat-sifat khas pada periode remaja”. Sedangkan kata delinquencymerupakankata konotasi seperti serangan, pelanggaran, kejahatan dan keganasan yang dilakukan oleh anak-anak muda di bawah usia 22 tahun (Kartono, 2017).Rosleny Marliani dalam bukunya menjelaskan bahwa kenakalan remaja merupakan perbuatan yang melanggar norma, aturan, atau hukum yang berlaku di masyarakat, yang dilakukan oleh orang yang memiliki usia remaja atau transisi masa anak-anak dan dewasa (Marliani, 2016).

Santrock memberikan penjelasan, bahwa kenakalan remaja merupakan kumpulan dari berbagai perilaku remaja yang tidak dapat diterima secara sosial sehingga terjadi tindakan kriminal (Santrock, 2007). Dari pendapat-pendapat tersebut, dapat dipahami secara sederhana, bahwa kenakalan remaja merupakan sebuah tindakan atau perilaku yang menyimpang atau melanggar norma, aturan, dan hukum dalam masyarakat yang dilakukan oleh seorang atau sekelompok remaja.

\section{Jenis-Jenis Juvenile Delinquency}

Tindakan kenakalan remaja yang sering dilakukan, digolongkan menjadi 3 jenis, yaitu:

Neurotic Delinquency. Kenakalan remaja jenis ini memiliki bentuk atau sifat yang pemalu, perasa, suka menyendiri, gelisah, dan merasa rendah diri. Remaja yang melakukan kenakalan jenis ini cenderung untuk melakukan perbuatan seperti: mencuri, 
melakukan tindakan agresif secara tiba-tiba dan tidak disertai alasan yang jelas. Hal ini dikarenakan pikiran mereka dikuasi oleh fantasinya sendiri (Apriansyah, 2021).

Unsocialized Delinquent. Jenis kenakalan remaja ini dikarenakan adanya keinginan remaja untuk melakukan pemberontakan terhadap orang yang memimpinnya, dengan cara menimbulkan rasa kebencian dan dendam. Remaja yang berani melakukan tindakan kenakalan ini, tidak memerlukan pujian atau hukuman. Hal ini dikarenakan mereka tidak merasa bersalah atas perbuatan yang telah dilakukannya (Marliani, 2016). Selain itu, remaja yang melakukan tindakan kenakalan remaja jenis ini tidak breani mempertanggung jawabkan perbuatannya. Mereka justru melemparkan perbuatannya yang salah dan tanggung jawab kepada teman-temannya.

Pseudo Social Delinguent. Remaja melakukan kenakalan remaja jenis ini sebagai bentuk kesetiaan dan loyalitas terhadap kelompok atau geng, dimana remaja tersebut menjadi bagian di dalamnya.Mereka berani melakukan kenakalantersebut bukan karena kesadaran diri sendiri, melainkan karena persepsi yang dimilikinya,yaitu remaja tersebut harus menjalankan peraturan dan kesepakatan-kesepakatan yang ada pada kelompok tersebut. Bagi remaja tersebut, kelompok dimana ia bergabung telah memberikan rasa aman kepada dirinya; hal ini membuat remaja tersebut selalu siap sedia untuk melakukan setiap kewajiban yang diberikan kepadanya, sekalipun kelompok tersebut tidak diterima oleh masyarakat.

\section{Bentuk Perilaku Juvenile Delinquency Pada Remaja}

Marliani menjelaskan ada beberapa bentuk perilaku kenakalan remaja yang sering dilakukan. Perilaku tersebut seperti:melakukan kebut-kebutan atau balapan liar di jalan sehingga mengganggu keamanan lalu lintas dan membahayakan diri sendiri maupun orang lain;bersikap ugal-ugalan, berandalan, dan urakan sehingga menimbulkan perkelahian antar kelompok (geng, sekolah, suku, dsb); berani membolos sekolah bersama-sama kemudian bersembunyi di tempat-tempat terpencil;berani melakukan tindakan kriminalitas seperti memeras, mencuri, mengancam, intimidasi;mengadakan atau bergabung kedalam pesta pora sampai mabuk-mabukan; melakukan free sex atau pemerkosaan;menggunakan narkotika;nekad melakukan tindakanpelecehan seksual di muka umum;dan sebagainya (Marliani, 2016). Semua bentuk perilaku kenakalan remaja ini biasa dilakukan secara individu maupun secara berkelompok. 


\section{Penyebab Remaja Berani Melakukan Juvenile Delinquency}

Ada beberapa teori yang memberikan penjelasan mengenai penyebab remaja berani melakukan tindakan kenakalan, seperti:

Teori Biologis. Remaja berani melakukan tindakan kenakalan remaja dikarenakan adanya faktor biologisnya, seperti melalui gen dari orangtua, pewarisan tipe-tipe kecenderungan fisik yang abnormal, atau juga melalui pewarisan kelemahan jasmani (cacat tubuh) sehingga membuat remaja tersebut cenderung untuk melakukan sifat-sifat kriminal.

Teori Psikogenis (Psikologis dan Psikiatris). Dalam teori ini, remaja berani melakukan tindakan kenakalan remaja dikarenakan adanya faktor psikologis atau kejiwaannya, seperti faktor kecerdasan, kepribadian, motivasi, sikap yang salah, fantasi, rasionalisasi, konflik batin, dsb. Teori ini menjelaskan bahwa, "perilaku kenakalan remaja merupakan bentuk 'penyelesaian' atau kompensasi dari masalah psikologis dan konflik batin dalam menanggapi stimuli eksternal/sosial dan pola hidup keluarga yang patologis".

Sebagai contohnya, dalam risetnya Kartono menemukan bahwa 90\% dari jumlah anak-anak yang melakukan kenakalan remaja berasal dari keluarga broken home (Kartono, 2017).Jika orangtua lalai dalam mendidik, tidak melakukan kontrol secara terus-menerus, serta tidak mengembangkan disiplin diri pada remaja,akan membuat remaja tersebut mudah terbawa dalam lingkungan sosialnya.

Teori Sosiogenis. Para sosiolog mempercayai bahwa kenakalan remaja yang terjadi murni disebabkan oleh faktor sosiologis (Kartono, 2017). Beberapa faktor tersebut antara lain: tekanan dari kelompok, peranan sosial, status sosial, dan sebagainya. Oleh karena itu, dapat dipahami bahwa faktor kultural dan sosial memiliki pengaruh yang kuat terhadap perkembangan seorang remaja. Sutherland berpendapat bahwa: "Semakin lama anak bergaul dan semakin intensif relasinya dengan anak-anak jahat lainnya, maka akan menjadi semakin lama pula pengaruhnya, dan semakin besar kemungkinan anak-anak remaja tersebut menjadi seorang kriminal.”

Teori Sub-kultur Delinkuensi. Teori inimenggabungkan antara sistem nilai, kepercayaan/keyakinan, ambisi-ambisi tertentu yang menstimulusakan timbulnya kelompok-kelompok remaja berandalan dan kriminal. Daya tarik yang digunakan untuk 
remaja mau melakukan tindakan kenakalan adalah pemberian hadiah, yaitu mendapatkan sebuah status sosial yang "terhormat" di tengah-tengah kelompoknya.

Teori ini juga menjelaskan bahwa perilaku kenakalan yang dilakukan oleh remaja disebabkan karena adanya sifat-sifat suatu struktur sosial yang memiliki pola yang khas dari lingkungan keluarga, tetangga, dan masyarakat dimana remaja tersebut ada. Masyarakat di sekitar remaja tersebut memiliki sifat seperti populasi padat, status sosial-ekonomi penduduknya relative rendah, kondisi fisik bangunan yang buruk, dan mengalami banyak disorganisasi familial dan sosial.

\section{Dampak Dari Tindakan Juvenile Delinquency}

Setiap bentuk kenakalan yang dilakukan oleh remaja mengandung resiko yang harus diterima. Resiko-resiko tersebut biasa mengarah pada diri remaja sendiri, keluarga secara khusus terhadap orangtua, dan tentunya masyarakat sekitar (Koswanto \& Hutagalung, 2020). Resiko yang ditimbulkan seperti:

Bagi diri sendiri. Resiko terhadap diri sendiri bagi remaja yang suka melakukan kenakalan adalah mereka terancam terkena berbagai penyakit jasmani, dikarenakan pola hidup yang tidak teratur. Secara mental, remaja tersebut juga dapat memiliki perkembangan mental yang buruk, cara berpikir yang tidak baik, dan kepribadiannya menyimpang dari segi mora yang pada akhirnya berani melakukan perbuatan yang melanggar etika dan sopan santun.

Bagi keluarga. Terhadap orangtua dan keluarga, remaja yang suka melakukan kenakalanakan mengganggu keharmonisan dalam keluarga. Harapan yang dimiliki orangtua terhadap anaknya sebagai penerus martabat keluarga,juga menjadi hilang. Selain itu, komunikasi terhadap orangtua juga terputus. Kalau remaja tersebut tidak mau berubah karakternya atau tetap melakukan tindakan kenakalan, maka orangtuaakanmemiliki rasa malu dan gagal atas dalam mendidik anaknya.

Bagi masyarakat sekitar. Remaja yang sering melakukan tindakan kenakalan, akan dipandang sebagai seseorang yang rusak moralnya. Masyarakat memberikan stigma negatif terhadap remaja tersebut, dan akan berlaku selamanya. Tetapi perlu disadari oleh remaja tersebut, bahwa hal ini juga bukan berarti tidak akanada kesempatan untuk bertobat dan meninggalkan karakter lamanya.

\section{Konsep Belief untuk Memberikan Kepercayaan yang Rasional}


Perkembangan sosial yang dialami oleh para remaja membawa mereka pada sebuah konflik mendekat-menjauh, dimana konflik ini merupakan permasalahan yang timbul dalam diri seseorang dikarenakan adanya dua rangsangan, yaitu rangsangan positif (teman-teman sebayanya) dan rangsangan negatif (keluarga).Keluarga dikatakan sebagai rangsangan yang negatif dikarenakan para remaja mulai tidak lagi memprioritaskan keluarga, namun pada hubungan sosial dengan teman-teman sebayanya. Oleh karena itu, remaja biasanya akan melakukan apa saja agar dapat diterima oleh komunitas atau kelompok yang dimana menurut pertimbangan pribadi, kelompok tersebut adalah tempat yang tepat untuk mereka.

Permasalahan utama ketika seorang remaja ingin bergabung dalam komunitas tersebut adalah penyesuaian diri. Di dalam komunitas tersebut, biasanya ada semacam persaingan antar masing-masing individu untuk menunjukkan keakuannya dan paling hebat diantara anggota kelompok. Hal ini secara implisit memerlukan tindakan-tindakan intelektual yang tepat dan kemampuan diri untuk mengendalikan atau menyeimbangkan dengan perkembangan emosi yang ada dalam diri remaja. Sebab, jika tidak demikian, maka akan membuat remaja tersebut nekad untuk melakukan tindakan-tindakan yang melanggar norma dalam kelompok tersebut ataupun norma yang ada di masyarakat.

Oleh karena itu, dalam menghadapi perkembangan sosial, seorang remaja memerlukan pembinaan atau pendampingan dari orang lain yang sudah dewasa. Tentunya, gereja mempunyai peranan penting dalam melakukan pendampingan terhadap remaja, agar mereka tidak salah dalam memilih komunitas atau pergaulan dan melakukan kenakalan-kenakalan yang dapat merugikan diri sendiri, keluarga, dan masyarakat. Untuk melaksanakan pendampingan terhadap remaja, gereja dapat menggunakan pendekatan REBT. Dengan menggunakan REBT ini, maka diharapkan gereja dapat memberikan nilai-nilai yang rasional terhadap remaja, sehingga mereka tidak salah dalam memilih komunitas atau kelompok sehingga terjerumus dalam tindakan kenakalan remaja. Beberapa nilai-nilai rasional yang dapat diberikan kepada remaja, seperti:

Penanaman nilai-nilai keagamaan. Pada remaja yang sedang menjalani perkembangan kerohanian, perlu diberikan nilai-nilai keagamaan. Hal ini dikarenakan penanaman nilai-nilai keagamaan pada remaja memiliki makna yang sama dengan penanaman nilai-nilai moral. Melalui nilai-nilai agama yang diberikan, remaja juga dapat mengerti mengapa ia ada di dunia ini, dan memberikan rasa aman kepada mereka. 
Oleh karena itu, gereja perlu mengambil peran dalam memberikan penanaman nilainilai yang sesuai dengan Alkitab. Jika tidak, maka remaja akan mengikuti nilai-nilai dunia yang dapat merugikan dirinya sendiri.

Menurut peneliti, ada beberapa teks di Alkitab yang dapat diberikan kepada remaja untuk memberikan pemahaman yang tepat mengenai dirinya, seperti:

\begin{tabular}{|c|c|}
\hline Tema & Ayat Alkitab \\
\hline Gambar diri & $\begin{array}{l}\text { Kejadian 1:27; Yeremia 1:5; Efesus 1:5; Efesus 2:10; } \\
\text { Filipi 3:20; Kolose 3:1-3; } 1 \text { Korintus 6:17; } 1 \text { Korintus } \\
\text { 6:19-20; Roma 6:5; } 2 \text { Korintus 5:17 }\end{array}$ \\
\hline Menghormati orangtua & $\begin{array}{l}\text { Imamat 19:32; Ulangan 5:16; Keluaran 20:12; Matius } \\
\text { 15:4; Markus 7:10; Markus 10:19 }\end{array}$ \\
\hline Pergaulan/komunitas & $\begin{array}{l}1 \text { Korintus 15:33; Lukas6:31; Lukas 4:24; Amsal } \\
\text { 22:24-25; Kol 3:12-14; Ams 27:5-6; Amsal 27:17. }\end{array}$ \\
\hline Didikan & Amsal 19:20; Amsal 1:2-3; Ibrani 12:11 \\
\hline
\end{tabular}

Teks-teks Alkitab tersebut dapat digunakan untuk memberikan nilai-nilai kekristenan kepada remaja. Dengan menanamkan nilai-nilai tersebut, maka diharapkan memberikan keyakinan atau kepercayaan yang rasional dalam diri remaja, sehingga tidak mudah untuk melakukan kenakalan remaja.

Pengendalian emosi. Remaja dapat mengalami pergolakan emosi di dalam dirinya karena beberapa faktor, seperti perubahan jasmani, perubahan pola interaksi dengan orangtua, perubahan interaksi dengan teman sebaya, perubahan pandangan luar/eksternal, dan perubahan interaksi dengan sekolah.Oleh karena itu, remaja perlu diberikan pembinaan untuk memiliki pengendalian diri yang kuat.

Untuk dapat mengendalikan emosi, seorang remaja dapat melakukan berbagai macam cara, seperti: tidak selalu menuntut kesempurnaan atau memasang target yang tinggi terhadap setiap apa yang dikerjakan, sehingga dapat memberikan toleransi kepada rasa frustasi yang muncul tetapi sesuai dengan kemampuan yang dimiliki; belajar untuk mengungkapkan rasa marah atau amarahnya dengan tepat seperti berolahraga, menekuni hobi, dsb dibandingkan dengan berkelahi; belajar untuk mengendalikan perilaku yang agresif yang dapat merugikan diri sendiri dan orang lain; dan mengurangi perasaan 
kesepian dan kecemasan ketika menjalin hubungan sosial dengan teman-teman sebayanya.

\section{Membangun komunikasi terhadap keluarga dan pembina gereja. Meskipun} remaja memiliki kecenderungan untuk memilih berkumpul dengan komunitasnya dibandingkan keluarga, komunikasi terhadap orangtua tetaplah harus dijaga.Dalam membangun komunikasi dengan keluarga, perlu adanya peran dari orangtua, maupun dari remaja itu sendiri.Orangtua diharapkan dapat menjadi sahabat bagi remajanya, sehingga remaja tersebut tidak merasa canggung bila ingin bercerita dengan orangtuanya.Remaja pun juga perlu membiasakan diri untuk berani terbuka terhadap orangtua dan menjalin komunikasi dengan sopan. Dengan membangun komunikasi yang efektif dan menyenangkan antara orangtua dengan remaja, maka akan memudahkan orangtua untuk memberikan didikan yang benar. Dalam hal ini, keluarga dapat dipandang sebagai komunitas yang pertama dan utama bagi remaja.

Selain keluarga, gereja juga perlu menyediakan sarana berupa komunitas yang sehat, agar remaja dapat bergabung dalam komunitas yang benar. Kunci dalam sebuah komunitas adalah penerimaan yang tulus terhadap masing-masing anggotanya. Komunitas dalam gereja dapat menjadi sarana yang efektif dalam memberikan nilainilai kekristenan bagi remaja. Hal ini dikarenakan remaja cenderung untuk lebih terbuka pada komunitasnya, dibandingkan pada orangtua. Oleh karena itu, remaja perlu memiliki komunitas yang sehat, membangun, dan berpedoman pada Firman Tuhan.

Membuat batasan-batasan yang jelas dalam pergaulan. Remaja perlu memberi batasan-batasan yang jelas dan tegas terhadap hal-hal yang tidak patut, seperti merokok, narkoba, obat-obatan terlarang, pornografi, dan sebagainya. Kata "tidak" mungkin menjadi jawaban yang sulit untuk diucapkan seorang remaja ketika mendapatkan ajakan dari komunitas atau teman-temannya. Tetapi ini dapat menjadi jawaban yang terbaik ketika remaja diajak untuk melakukan hal-hal yang tidak patut.

Jika remaja tersebut tidak berani memberikan batasn-batasan yang jelas dalam pergaulannya, maka suatu saat mereka akan merugikan diri sendiri dan keluarga. Dan tentunya masa remaja tersebut akan terbuang percuma dan masa depan menjadi suram.

\section{SIMPULAN}


REBT dapat digunakan untuk mengurangi keyakinan atau kepercayaan yang irasional dan menguatkan keyakinan rasional melalui pembelajaran kognitif, perasaan, dan perilaku. Oleh karena itu, REBT dapat mengubah kepercayaan irasional yang memicu emosi negatif remaja, menjadi kepercayaan yang rasional sehingga dapat menanggulangi tindakan-tindakan kenakalan pada seorang remaja. Nilai-nilai rasional yang harus diajarkan kepada remaja dalam mengubah kepercayaan irasional menjadi rasional, yaitu nilai-nilai keagamaan, pengendalian emosi, komunikasi terhadap keluarga dan pembina gereja, serta membuat batasan-batasan yang jelas dalam pergaulan.

\section{DAFTAR PUSTAKA}

Aji, N. H. P. (2021, July 17). Viral "Challenge Malaikat Maut” Berujung Seorang Remaja Tewas, Ternyata Sudah 5 Kali Lakukan Aksi. Tribunsolo.Com. Https://Solo.Tribunnews.Com/2021/07/17/Viral-Challenge-Malaikat-MautBerujung-Seorang-Remaja-Tewas-Ternyata-Sudah-5-Kali-Lakukan-Aksi

Apriansyah, A. (2021). Partisipasi Masyarakat Dalam Penanggulangan Kenakalan Remaja Balapan Liar Di Desa Sangatta Utara. Ejournal Sosiatri-Sosiologi, 2021(1), 92-109.

Erford, B. T. (2020). 40 Teknik Yang Harus Diketahui Setiap Konselor (2nd Ed.). Pustaka Pelajar.

Erlina, N., \& Sari, D. N. (2016). Pengaruh Pendekatan Rational Emotive Behaviour Therapy (Rebt) Terhadap Peningkatan Kecerdasan Emosional Pada Peserta Didik Kelas VIII SMPN 6 Bandar Lampung Tahun Ajaran 2015/2016. Konseli, 3(2), 303-316.

Fhadila, K. D. (2018). Menyikapi Perubahan Perilaku Remaja. Jurnal Penelitian Guru Indonesia, 2(2), 17-23. Https://Doi.Org/Https://Doi.Org/10.29210/02220jpgi0005

Geldard, K., \& Geldard, D. (2011). Konseling Remaja (1st Ed.). Pustaka Pelajar.

Hartati, Sri \& Rahman, I. K. (2018). Konsep Pendekatan Rational Emotive Behavior Therapy (REBT) Berbasis Islam Untuk Membangun Perilaku Etis Siswa. Genta Mulia, Vol 8(No 2), 13-26. File://C:/Users/ASUS/Downloads/115-207-1-SM (1).Pdf

Hasan, I. (2008). Analisis Hasil Penelitian Dengan Statistik. Bumi Aksara.

Hurlock, E. . (1995). Perkembangan Anak (1st Ed.). Erlangga.

Kartono, K. (2017). Patologi Sosial 2 Kenakalan Remaja. PT Grafindo Persada.

Komalasari, G., Wahyuni, E., \& Karsih. (2011). Teori Dan Teknik Konseling. Indeks.

Koswanto, A., \& Hutagalung, M. A. (2020). Menyelami Dunia Remaja Zaman Now (2nd Ed.). Ekumene Literature.

Koswanto, A., \& Hutagalung, M. A. . (2019). Menyelami Dunia Remaja Zaman Now (1st Ed.). Ekumene Literature.

Marliani, R. (2016). Psikologi Perkembangan Anak\&Remaja (1st Ed.). CV Pustaka Setia.

Marlina, Ningsih, Y. T., Fikry, Z., \& Fransiska, D. R. (2021). Panduan Pelaksanaan REBT Berbasis BISINDO (A. Santika (Ed.)). CV Afifa Utama. 
Nopiansyah, A. (2021, April). Kenakalan Remaja Zaman Sekarang. Aljabar News.

Rossa, V. (2021). Ikut Tantangan Viral Di Tiktok, Remaja 13 Tahun Terlalap Api.

Suara.Com. Https:/Www.Suara.Com/Lifestyle/2021/05/31/133302/Ikut-

Tantangan-Viral-Di-Tiktok-Remaja-13-Tahun-Terlalap-Api?Page=All

Sanjaya, A. (2018). Pastoral Konseling Kepada Remaja Kristen Indonesia Dalam

Menghadapi Pergaulan Bebas. Missio Ecclesiae, 7(1), 141-163.

Santrock, J. W. (2007). Perkembangan Anak. Erlangga.

Supiandi, A. (2021). Remaja Bergerombol Acungkan Celurit Di Karawang Viral Di

Sosmed. Inewsjabar.Id. Https://Jabar.Inews.Id/Berita/Remaja-Bergerombol-

Acungkan-Celurit-Di-Karawang-Viral-Di-

Sosmed? $\mathrm{Ga}=2.209124882 .1674900119 .1640674236-1573614680.1624112535$

Surjaya, A. M. (2021). Tawuran Tewaskan Remaja Di Cikarang Dipicu Saling Ejek Di

Medsos. Okenews.

Https://Megapolitan.Okezone.Com/Read/2021/10/27/338/2492307/Tawuran-

Tewaskan-Remaja-Di-Cikarang-Dipicu-Saling-Ejek-Di-Medsos

Widodo, B. (2016). Kenakalan Remaja Dan Strategi Pendampingan Pastoral. 6(3), $52-$

74. Https://Doi.Org/Https://Doi.Org/10.34150/Jpak.V6i3.148 